\title{
Problems in Legal Regulation of Third-party Payment of Internet Finance
}

\author{
Xiangqian Han \\ Tianjin University, Tianjin, 300072, China
}

Keywords: Legal regulation, Third-party payment, Internet finance

\begin{abstract}
The emergence of third-party payment of internet finance is of great practical significance for the reform of state-owned monopoly financial institutions. However, the third-party payment has not yet developed, and the regulation has not been incorporated into the legal track. This paper analyses the civil liability triggered by internet risk and finance risk and the criminal liability triggered by illegal fund-raising, credit card arbitrage and money laundering risk. Based on the analysis, the paper lists the legal regulation suggestions of third-party payment of internet finance to provide some references for the relative researchers.
\end{abstract}

\section{Introduction}

In recent years, with the continuous development of internet technology and the popularity of the emerging field of e-commerce gradually into the public view [1]. It makes the emergence of people's consumption concepts and habits have undergone changes in turn the world upside down, more importantly, it appears to stimulate the development of domestic consumption. With the popularity of e-commerce and the development of Internet technology, traditional financial and Internet technologies have penetrated each other, forming the new field of Internet finance. Since the emergence and development of the third-party payment platform, many years of continuous exploration and innovation have made remarkable achievements. After fierce competition and elimination, the development status of the third-party payment platform has stabilized. The emergence of third-party payments not only brings great convenience to our lives, but also brings more income for banks and other financial institutions. But the emergence of any new thing has two sides. The third-party payment is no exception. It not only brings convenience and interest to us, but also makes our financial system face more challenges and unforeseen risks. But if we want to avoid risk and restrict its development, it is obviously against the natural development rule of things. But the emergence of the third-party payment is an inevitable trend of economic development. It plays an important role in promoting the integration and promotion of Internet finance. The third-party payment to the intermediary service agencies, it use the network to provide payment and settlement, clearing and other services for individuals and businesses, in the transaction process, due to time and space and other hard obstacles, both parties may not conduct face-to-face transactions, receipt and collection has a certain time lag, which leads to distrust between the two sides of the problem however, the third-party payment platform is a good solution to this problem, as a middle platform payment, it is independent of the seller and the buyer, and has a certain financial strength and credibility of the guarantee [2].

\section{Civil Liability of Third-party Payment of Internet Finance}

\subsection{Civil Liability triggered by Internet Risk}

Electronic payment system is composed of software and hardware configuration and external support to its internal together, its stability is a prerequisite and foundation of Internet financial services, the third-party payment institutions as principal payment in the relationship between the trustee, responsible for the system maintenance and ensure the stable operation of the collateral 
obligation. If the user's financial instructions cannot be executed due to the failure of the electronic payment system, it should be regarded as the third-party payment institution has not completed the entrusted matter, and the third-party payment institution shall bear the corresponding liability for breach of contract. 2. electronic payment operation risk in the Internet era, network hackers, etc. will use electronic pickpockets every links of the electronic payment transaction system, penetration of both sides, steal trading accounts, destroy the normal electronic payment, although the parties will take the protection measures such as the wall of the stolen funds but the transaction situation still occur. In this case, because the third-party payment institutions have no obvious fault in the theft of financial capital, the liability principle of fault liability is adopted based on the entrustment contract, and the third-party payment institutions do not have to bear the liability for breach of contract under the entrusted payment relationship. In practice, the third-party payment institutions to expand Internet financial funds tend to increase for additional obligation to pay the loss guarantee in agreed with the user, such as payment of insurance loss or self-compensation, then in accordance with the agreement of both cases, the third-party payment institutions will need to pay the user assume responsibility for losses. But at the same time, should pay attention to, and the third-party payment institutions did not complete the matters entrusted to bear the liability for breach of contract, the third-party payment agencies guarantee liability does not come from its legal obligations, its scope of responsibility depends entirely on the user's agreement, both sides clearly exclude investment losses, loss of profits in the agreement, should be is valid [3].

\subsection{Civil Liability triggered by Finance Risk}

Because our country has a strict supervision and control mechanism for financial markets, service providers are generally required to obtain license corresponding to be engaged in the sale of financial products business, if the third-party payment institutions posted on the website does not have the corresponding main qualification of the sale of financial products, and thus lead to users of investment losses, the third-party payment institutions this behavior constitutes a false statement, should bear the corresponding tort liability. In addition, the third-party payment institution usually stipulate similar clauses to the issuer of the financial product issuer or the exemption from uploading information in the service agreement with the user, but the terms belong to the category of the contract providers who are exempt from their responsibilities, which should be regarded as invalid. As a trustee in the entrusted payment relationship, the third-party payment institution has the obligation to allocate financial funds according to the customer's instructions and the agreement between the two parties. If the breach of the contract obligation causes user's investment loss, the third-party payment institution shall bear the liability for breach of contract. It is worth noticing that when some of the third-party payment institutions appear in the above circumstances, the users should be compensated instead of the compensation. Meanwhile, the investment losses will be excluded from the compensation scope in their format contracts. The author thinks that compensation is not a remedy for breach of contract, but it is usually based on moral level, but it is a violation of the third-party payment institution because of improper transfer and payment. Loss compensation includes direct loss and available interest loss, and investment loss is a category of available interest. The third-party payment institution will not be excluded from the scope of liability. These are the main qualification of the third-party payment institutions engaged in the business of Internet financial payment in the necessary requirements, once do not have these qualifications and payment business, the third-party payment institutions will be subject to the Department in charge of the corresponding punishment, even halted payment related business [4].

\section{Criminal Liability of Third-party Payment of Internet Finance}

\subsection{Criminal Liability triggered by Illegal Fund-Raising}

As a means of financial innovation, Internet finance has become a kind of financial service which the enterprises and residents like very much. It is also because the Internet Financial audience is more 
and more high, some of the use of Internet finance to engage in illegal financial activities is more and more. Among them, the use of Internet to collect funds illegally is one of the most serious financial shocks to the Internet. As a result, many social events have been triggered, and many social contradictions have been broken out, and many enterprises and the masses have been injured and affected by the illegal capital collection. Because of this, the act of engaging in illegal fund-raising activities in the name of Internet finance must be severely punished, resolutely prevented and dealt with quickly, to avoid hurting more businesses and people and bring about social stability. The occurrence of illegal fund-raising cases is related to the degree of economic activity and the liquidity of the crime. The occurrence of the eastern region will have a continuous spread effect on the central and western regions. There are some crimes in the East has become obsolete, the criminals will relatively underdeveloped areas to repeat the stock tricks. In addition, the design of some regional systems is relatively imperfect, and it is easy to be drilled by criminals. The payment deposit received by the payment institution must be paid in full to the special deposit account opened by the payment institution in the bank. No unit or individual may misappropriate, occupy or borrow the payment of the payment of the payment of the customer without authorization. If the third-party payment platform is irregularities, the payment of payment for the customer is not specially managed, which may constitute a pool of funds for the precipitation. The purpose of individual customers to adopt quota management is to use payment account and balance payment business, and the direct purpose is to prohibit excessive precipitation funds in the payment account of Payment institutions. If the third-party payment platform misappropriated the customer, it may constitute the crime of encroachment, the crime of illegally absorbing the public deposit or the crime of collecting funds.

\subsection{Criminal Liability triggered by Credit Card Arbitrage}

The so-called credit card cash generally refers to the credit card holders who do not withdraw cash through banks, but collude with merchants, making use of POS machines and tools of merchants to make false high consumption, making a fictitious transaction and obtaining cash after paying the so-called fee. Since banks can use cash to withdraw cash, why do some cardholders collude with merchants to carry out credit card cash? Many banks have credit restrictions on cash withdrawals through ATM machines or bank counters. The extraction of cash through the bank is far from satisfying the needs, and must choose to collude with the merchants, use false transactions, and collect enough cash. In the past, the perpetrator usually colluded with the POS contractor in the crime of credit card fraud. On the third-party payment platform, the perpetrator can easily realize credit card arbitrage at lower costs through the trading rules paid by the third-party. The most direct is the credit card for the third-party payment platform account recharge, through savings card withdrawals. In 2015 the central bank issued the ban, more than third-party payment operators to stop credit card recharge channel, but by the end of 2016 there are still in this way can a fish escaped through the Seine, credit card cash. In addition, the actor also uses credit card to purchase his own fake merchandise on the e-commerce website to cash in or to cash in with the third-party payment authorized by credit card. In recent years, there have been many incidents in China using the third-party payment platform to carry out credit card cash. Despite the prohibition of credit card arbitrage in the terms of service of the third-party payment platform, it is difficult to investigate and deal with the imperfect supervision system.

\subsection{Criminal Liability triggered by Money Laundering Risk}

Because through the third-party payment platform is carried out through the network platform, and the platform is free from outside the banking system, the payment platform is placed between the parties to the transaction, and the flow of funds to the bank recourse shield, interference bank for transaction monitoring, it is difficult for the regulator to track the real situation of the transaction. Using this characteristic, the criminals will make the cash flow through the third-party payment system to conceal the source and the flow of funds and make cross-border payment to change illegal transactions. Currently, the risk of money laundering implied by the third-party payment platform 
mainly includes the following situations. This is the most common type of crime using the third-party trading platform for money laundering. The behavior of people registered account entry false merchandise information, from the electricity supplier website self, through the third-party payment platform to complete the transaction for the transfer of funds from. The authentication of many commercial buyers and sellers are not strict, false trading easy, through this form can reach the source and nature of the funds to cover up. The perpetrator remotely controls the payment terminals of other people's computers and mobile phones through the Trojan horse virus. When users engage in online transactions, trojan virus automatically activates, instantly steal user information and transaction information, automatically grab bank entries, fabricate false orders to deceive users, and simultaneously transfer user funds through third-party payment channels, such as online game platform. Then the hackers quickly bought the game equipment, using the victim funds transferred to the platform to further the money laundering.

\section{Legal Regulation Suggestions of Third-party Payment of Internet Finance}

Internet finance is not simply moving the financial business to online development and operation, but also integrating the traditional operation mode of the financial industry by using Internet technology, providing a new platform for users to carry out financial activities more conveniently. The Internet can improve the efficiency of financial capital and financial allocation, reduce operating costs, enhance the level of financial services, and Internet banking is undoubtedly a major financial innovation, now become benign extension and supplement of the financial system, but also represents the future development trend of financial industry. As the initial form and main form of Internet finance, the third-party payment occupies a pivotal position in the Internet financial industry. It not only promotes the diversified development of Internet finance, but also integrates various types of financial services. Although there are some big criminal risks that cannot be ignored, it is more important to value the great innovation value it contains. For example, money laundering, credit card cash and other serious violations of legal interests should be criminalization, but the intervention of criminal law should not be excessive. Otherwise, it is bound to be counterproductive. In our country, the development of an industry or a business mode is always full of thorns and frustrations. To rigid administrative supervision and strict criminal law provisions often become a stumbling block for its development. Such examples are everywhere in history. Therefore, for the third-party payment, the position of the criminal law should be to keep prudent, tighten the crime circle, avoid the expansion of the penalty, so as not to block or even stifle its development. In modern society, the width and the requirements of criminal policy with means of punishment, but also to get rid of from the psychology of criminal law in imperial and superstition.

\section{Conclusions}

The emergence of Internet finance, such as third-party payment, is of great practical significance to the reform of state-owned monopoly financial institutions, such as banks. Regulators' attitude towards them is to encourage financial innovation to a new industry as much as possible, though it should be incorporated into the legal system from a regulatory perspective, but it should also give more tolerance to its negative effects.

\section{References}

[1] Lu Zhigang. On the Re-regulation of the Online Third-party Payment Format Contract - Based on the Perspective of Behavioral Law and Economics [J]. Journal of Political Science and Law, 2017(5): 111-120.

[2] Xu Boqiang. On the Legal Risk of the Third-party Payment and Its Criminal Law Position [J]. Taxation and Economy, 2017(5): 38-42. 
[3] Zhang Wenqing, Li Mingxuan, Meng Zan. An Empirical Research on Impact of Internet Finance on the Traditional Monetary Policy [J]. Journal of Yantai University (Philosophy and Social Science Edition), 2015, 28(3): 98-104.

[4] Xu Xinjia. On Application Of Law Of The Third-party Cross-border Electronic Payment Disputes - In The View Of Consumers Protection [J]. Citizen and Law, 2016(6): 29-32. 